\title{
Pendampingan Sosial Bagi Lanjut Usia Berbasis Kearifan Lokal Masyarakat
}

\author{
Rudi Hermawan \\ Pendidikan Nonformal, Universitas Negeri Yogyakarta \\ rudihermawan.2017@student.uny.ac.id
}

\begin{abstract}
Abstrak
Artikel ini bertujuan untuk mendeskripsikan bentuk-bentuk pendampingan sosial bagi orang yang lanjut usia di Desa Sidoluhur. Lanjut usia sering mendapat anggapan bahwa mereka selalu menggantungkan dirinya dengan orang lain dan menjadi beban dalam keluarganya. Padahal para lanjut usia ini juga termasuk menjadi bagian dari masyarakat Desa Sidoluhur. Para lanjut usia perlu diberikan suatu wadah agar mereka masih mampu untuk produktif melalui pendampingan sosial bagi lanjut usia. Penelitian ini menggunakan pendekatan kualitatif dengan metode deskriptif. Informan dalam penelitian ini adalah masyarakat Desa Sidoluhur yang memiliki orang yang lanjut usia di lingkungan keluarganya dan lansia yang aktif mengikuti kegiatan-kegiatan. Tempat penelitian ini di Desa Sidoluhur. Teknik pengumpulan data menggunakan observasi, wawancara, dan dokumentasi. Teknik analisis data dalam penelitian ini adalah reduksi data, penyajian data, dan penarikan kesimpulan. Hasil temuan menunjukkan bahwa program pendampingan sosial lanjut usia di Desa Sidoluhur yaitu pendampingan lanjut usia pada aspek sosial, kesehatan, ekonomi, dan spiritual. Nilainilai kearifan lokal masyarakat yang terdapat dalam proses pendampingan sosial lanjut usia yaitu saling menghormati dan menghargai; saling menjaga kerukunan; dan menjaga budaya gotong royong.
\end{abstract}

Kata kunci : pendampingan sosial, lanjut usia, kearifan lokal

\begin{abstract}
This article aims to describe the forms of social assistance for elderly people in the village of Sidoluhur. The elderly often get the assumption that they always depend themselves on others and become a burden in their families. Even though these elderly people also belong to the community of Sidoluhur Village. The elderly need to be provided with a forum so that they are still able to be productive through social assistance for the elderly. This research uses a qualitative approach with descriptive methods. The informants in this study are the people of Sidoluhur Village who have elderly people in their family and elderly who actively participate in activities. This research site is in Sidoluhur Village. Data collection techniques using observation, interviews, and documentation. Data analysis techniques in this study are data reduction, data presentation, and drawing conclusions. The findings show that the social assistance program for the elderly in Sidoluhur Village is the elderly assistance in social, health, economic, and spiritual aspects. The values of the local wisdom of the people contained in the process of elderly social assistance are mutual respect and respect; maintaining harmony with one another; and maintain mutual cooperation culture.
\end{abstract}

Keywords : social assistance, elderly, local wisdom

\section{PENDAHULUAN}

Setiap orang akan mengalami tahapan hidup dimana orang itu akan menjadi tua. Orang yang menjadi tua ini bisa disebut orang yang lanjut usia.
Orang lanjut usia mengalami penuaan dimana akan terjadi penurunan fungsifungsi bagian tubuh yang menyebabkan terbatasnya segala aktivitas yang bisa membebani tubuh. Ada sebagian 


\section{Diklus: Jurnal Pendidikan Luar Sekolah, 2 (3), September 2019 - 95 \\ Rudi Hermawan}

keluarga maupun masyarakat tertentu yang memiliki lanjut usia dapat menjadi beban, oleh karena itu keluarga atau masyarakat tertentu tersebut menitipkan orang yang lanjut usia ke panti sosial. Keadaan yang seperti ini kurang baik karena keluarga dan masyarakat tertentu tersebut tidak memiliki rasa kepedulian terhadap lanjut usia.

Adanya masalah yang dihadapi lanjut usia perlu adanya kepedulian dari keluarga yang memiliki lanjut usia maupun masyarakat yang memberikan suatu wadah untuk lanjut usia sebagai bentuk kepedulian. Kepedulian kepada lanjut usia dapat diwujudkan dengan menciptakan suasana yang baik dan kondusif baik di lingkungan keluarga maupun masyarakat. Suasana yang baik dapat memberikan lanjut usia merasa dirinya masih berguna dan dapat berprestasi atau masih bisa produktif sehingga lanjut usia merasa senang dan bahagia.

Lanjut usia ini memerlukan dukungan sosial dari lingkungan keluarganya, temannya, dan masyarakat dimana lanjut usia tinggal. Dukungan sosial ini dapat berupa saran, bantuan nyata, dan tingkah laku yang diberikan oleh pendamping kepada lanjut usia dalam lingkungan sosialnya. Dukungan sosial ini dapat berasal dari individu (relawan) atau kelompok.

Menurut Undang-undang No 13 Tahun 1998 tentang Kesejaheraan Sosial Lanjut Usia yang menyatakan bahwa lanjut usia merupakan orang yang telah mencapai usia 6o tahun ke atas. Pengertian lanjut usia ini hanya dilihat dari sudut pandang usia, sedangkan yang termasuk dalam kategori lanjut usia itu ada 2 yaitu lanjut usia yang masih produktif dan yang tidak produktif. Lanjut usia juga dapat berfungsi sosial dengan baik dalam keluarganya maupun masyarakat dimana lanjut usia tinggal.
Kedudukan lanjut usia dalam keluarga dapat sebagai orang yang paling tua sebagai pemberi nasihat kepada yang lebih muda. Selain itu lanjut usia masih memiliki peran seperti pendampingan kepada generasi penerus, berbagai pengalaman hidup, dan sebagai narasumber kearifan lokal yang dapat dibutuhkan oleh masyarakat atas pengalaman yang dimiliki lanjut usia. Penyaluran peranan lanjut usia ini dapat mendatangkan kebahagiaan tersendiri bagi lanjut usia. Oleh karena itu, lanjut usia tidak seharusnya diabaikan begitu saja karena lanjut usia masih mampu memberikan kontribusinya dan masih bisa terlibat dalam pengambilan keputusan di dalam lingkungan keluarganya.

Struktur sosial yang ada di masyarakat juga membuat kehidupan lanjut usia menjadi berubah. Struktur keluarga yang sebelumnya keluarga besar telah berubah menjadi menjadi keluarga inti. Lanjut usia yang sebelumnya tinggal bersama dengan keluarga besarnya, sekarang lanjut usia tersebut terpisah dengan keluarganya. Keluarga yang memiliki lanjut usia di tempat tinggalnya cenderung tidak peduli dan menghindari karena dianggap sebagai beban keluarga.

Berdasarkan Biro Tata Pemerintahan Setda DIY pada tahun 2016 jumlah penduduk lansia di Kabupaten Sleman berjumlah 88.115 jiwa. Angka tersebut termasuk tinggi jika dibandingkan dengan kabupaten lainnya di propinsi Daerah Istimewa Yogyakarta ini. Data tersebut dapat menunjukkan bahwa jumlah penduduk yang lanjut usia ini akan terus meningkat tiap tahunnya. Peningkatan jumlah penduduk lanjut usia dapat menimbulkan berbagai masalah ekonomi, sosial, dan kesehatan. Hal tersebut dapat memberikan masalah jika tidak diimbangi dengan pemberian 


\section{Diklus: Jurnal Pendidikan Luar Sekolah, 2 (3), September 2019 - 96 \\ Rudi Hermawan}

fasilitas terhadap lanjut usia dengan memberikan pelayanan sosial yang berwujud pendampingan sosial.

Dalam sudut pandang ekonomi, penduduk yang tergolong lanjut usia dipandang sebagai beban daripada sumber daya yang dapat dimanfaatkan segala potensi yang dimiliki. Sedangkan dalam sudut pandang sosial, penduduk yang tergolong lanjut usia merupakan segolongan atau sekelompok sosial tersendiri. Masalah kesehatan juga dialami lanjut usia akibat dari penurunan fungsi dari indera pendengaran dan penglihatan. Selain itu lanjut usia juga mengalami kelemahan fungsi organ vital, penurunan fisiknya, dan memiliki berbagai macam penyakit. Masalah yang dihadapi lanjut usia secara psikologis yaitu mengalami kesepian, merasa asing dari lingkungan sekitarnya, ketidakmampuan, dan ketergantungan lanjut usia bahkan sampai mengalami keterlantaran. Lanjut usia juga masih memiliki sikap kemandirian. Lanjut usia masih mampu untuk melakukan aktivitas sehari-hari dalam memenuhi kebutuhan hidupnya. Masalah-masalah yang dihadapi oleh penduduk lanjut usia dapat berkaitan dengan keadaan jasmaniah, rohaniah, dan psikologinya. Keadaan yang demikian mendorong untuk segera dibuatkan program pendampingan sosial bagi para lanjut usia. Program pendampingan sosial ini dapat berupa pelayanan dan perlindungan sosial bagi lanjut usia.

Lanjut usia adalah orang yang kirakira mulai terjadi pada usia 6o tahun ditandai dengan adanya perubahan yang bersifat fisik dan psikologis yang cenderung mengarah ke penyesuaian diri yang buruk dan hidupnya bahagia (Hurlock, 1980). Lanjut usia memiliki kebutuhan hidup yang sama seperti pemuda atau orang yang masih produktif lainnya yaitu ingin dapat hidup yang sejahtera. Lanjut usia merasa kurang produktif diakibatkan pensiun dari pekerjaannya, akan teteapi lanjut usia masih memiliki kebutuhan ekonomi yang berhubungan dengan kesehatan lanjut usia. Oleh karena itu untuk memenuhi kebutuhan akan ekonominya lanjut usia mencari alternative pekerjaan lain yang sesuai dengan kemampuan fisik dan pikirannya untuk mencukupi kebutuhan hidupnya. Kebutuhan hidup yang diinginkan lanjut usia yaitu makanan bergizi, pemeriksaan kesehatan, rumah yang sehat, keadaan rumah yang aman, dan kondusif. Lanjut usia juga memiliki kebutuhankebutuhan yang terdiri dari berbagai aspek yaitu aspek fisik, psikis, mental/ spiritual, sosial/ budaya, dan ekonomi. Jika kebutuhan lanjut usia tidak dapat terpenuhi dapat menimbulkan permasalahan yang lebih kompleks bagi lanjut usia. Maka, diperlukan pendampingan sosial bagi lanjut usia untuk membantu dalam pemenuhan kebutuhannya baik dalam aspek kesehatan untuk memenuhi kebutuhan fisik dan psikisnya, pendampingan pada aspek sosial untuk memenuhi kebutuhan sosial budaya lanjut usia, pendampingan pada aspek ekonomi agar masih dianggap produktif, dan pendampingan pada aspek spiritual untuk kebutuhan mental spiritualnya.

Pendampingan sosial merupakan aktivitas yang diperlukan untuk mendorong terjadinya pemberdayaan sosial secara maksimal untuk lanjut usia. Pendampingan sosial ini dilatarbelakangi oleh adanya kesenjangan pemahaman antara pihak sasaran dan yang memberikan bantuan pendampingan. Kesenjangan tersebut diakibatkan adanya perbedaan dan keterbatasan informasi dari kondisi sebenarnya dari aspek sosial, budaya, dan ekonomi. Maka dari itu diperlukan pendampingan yang 


\section{Diklus: Jurnal Pendidikan Luar Sekolah, 2 (3), September 2019 - 97 \\ Rudi Hermawan}

berbasis pada kondisi sebenarnya dilapangan agar tepat sasaran. Pendampingan lanjut usia dalam bentuk pelayanan sosial merupakan proses interaksi antara yang memberikan pelayanan dengan yang menerima pelayanan sosial (Depsos, 2009). Pelayanan sosial ini merupakan upaya memberikan kemudahan untuk mengidentifikasi kebutuhan serta memecahkan masalah yang dihadapi dan mendorong tumbuhnya keberanian untuk mengungkap realitas hidup dan melakukan aktivitas guna meningkatkan kualitas hidup penerima layanan yaitu masyarakat lanjut usia.

Pendampingan sosial biasanya hanya mengikuti kebijakan dari program pemerintah. Hal ini menyebabkan suatu bentuk pendampingan sosial kurang memperhatikan keadaan atau karakteristik masyarakat sasaran program. Maka dari itu, perlu adanya kebijakan yang baru yang dalam perencanaan programnya berbasis pada kearifan lokal masyarakat lokal setempat. Kearifan lokal memiliki nilai baik yang diikuti dan dipercayai oleh masyarakat secara turun temurun (Dahliani, 2015). Dalam suatu tradisi suatu masyarakat terdapat kebiasaan yang sudah dilakukan oleh masyarakat tersebut dalam bentuk gagasan, nilai, dan pandangan. Gagasan, nilai, dan pandangan tersebut akan selalu diikuti, dianut, dan dipercayai oleh setiap anggota masyarakat daerah tertentu.

Rachmadhani (2011) menyatakan bahwa kearifan lokal memiliki fungsi sebagai penanda identitas. Maksudnya kearifan lokal memiliki peran dan fungsi sebagai elemen perekat; sebagai unsur kultural masyarakat; sebagai warna dalam sebuah komunitas; sebagai pengubah pola pikir dan hubungan timbal balik individu dengan kelompok; dan sebagai unsur mendorong terbangunnya kebersamaan.

Berdasarkan Perda DIY No 5 Tahun 2011, Pendidikan yang berbasis budaya ialah pendidikan yang diselenggarakan oleh satuan pendidikan yang berbasis budaya. Kelompok layanan pendidikan yang dimaksud ialah satuan pendidikan yang ada pada jalur formal, nonformal, dan informal. Dalam hal ini satuan pendidikan yang digunakan perannya ialah pendidikan nonformal dan informal yang berwujud suatu organisasi sosial dalam masyarakat yang mengedepankan nilai-nilai luhur budaya lokal.

Organisasi sosial sebagai sarana untuk menyelenggarakan suatu program pemberdayaan masyarakat perlu memperhatikan pembelajaran yang berbasis kearifan lokal. Adanya pembelajaran berbasis kearifan lokal memberikan manfaat akan kesadaran pada kearifan lokal daerah yang dimilikinya, seperti upacara adat dan nilai/ norma yang dianut masyarakat setempat (Sa-ngiamwibool, 2012). Oleh karena itu perlu membentuk pendamping-pendamping pada tingkat lokal masyarakat agar mereka mampu memberikan pendampingan kepada lanjut usia.

\section{METODE}

Penelitian ini menggunakan pendekatan kualitatif dengan metode deskriptif. Penelitian kualitatif merupakan pendekatan penelitian yang mengkaji fenomena, gejala, fakta, dan kejadian yang terjadi di masyarakat. Penelitian kualitatif biasanya menekankan konteks sosial karena makna tindakan sosial, peristiwa, atau pernyataan sangat tergantung pada konteks dimana kejadian itu muncul (Neuman, 2014),

Penelitian ini dilakukan di Desa Sidoluhur, Kecamatan Godean, 


\section{Diklus: Jurnal Pendidikan Luar Sekolah, 2 (3), September 2019 - 98 \\ Rudi Hermawan}

Kabupaten Sleman, DI Yogyakarta. Informan dalam penelitian ini yaitu orang-orang lanjut usia yang produktif dan aktif mengikuti kegiatan-kegiatan. Data diperoleh dengan menggunakan metode observasi, wawancara, dan dokumentasi. Teknik pengumpulan data yang digunakan yaitu reduksi data, penyajian data, dan penarikan kesimpulan.

\section{HASIL DAN PEMBAHASAN}

Lanjut usia masih memiliki kebutuhan yang harus dipenuhi dan memiliki berbagai masalah yang disebabkan oleh penurunan baik fisik dan psikis lanjut usia tersebut. Pendampingan sosial yang ada dimasyarakat perlu disesuaikan dengan yang dibutuhkan oleh lanjut usia. Pendampingan sosial juga diperlukan bagi lanjut usia dalam membantu menyelesaikan masalah yang sedang dihadapi lanjut usia. Pendampingan sosial bagi lanjut usia ini merupakan wujud dari upaya untuk memberikan kemudahan bagi lanjut usia dalam mengidentifikasi apa saja yang menjadi kebutuhannya. Selain itu, juga memberikan upaya untuk kemudahan dalam memecahkan yang sedang dihadapi lanjut usia.

Lanjut usia perlu mendapatkan perhatian, bimbingan, dan pendampingan dari pihak lain untuk mendorong terwujudnya kesejahteraan sosial bagi lanjut usia. Pemberdayaan yang berwujud pendampingan sosial ini bertujuan agar lanjut usia mampu untuk menikmati taraf hidup yang baik dan wajar. Hal ini ditandai dengan harapan lanjut usia mampu untuk mengatasi masalahnya sendiri, mampu menjalankan fungsi sosialnya dengan baik, dan mampu mengambil peran dalam kegiatan-kegiatan yang ada di masyarakat.
Pendampingan sosial ini mendorong lanjut usia untuk dapat memberikan peran dan fungsinya saat ikut berpartisipasi aktif dalam kegiatankegiatan yang dapat berguna untuk kebahagiaan lanjut usia. Pendampingan sosial yang ada di Desa Sidoluhur ini memiliki tujuan untuk mewujudkan kualitas lanjut usia agar tetap bahagia dan sejahtera. Selain itu juga dapat menjalankan fungsi dan peran sosialnya dalam keterbatasan yang dimiliki oleh lanjut usia.

1. Bentuk-bentuk pendampingan sosial untuk lanjut usia

a) Pendampingan lanjut usia pada aspek sosial

Pendampingan pada aspek sosial memiliki tujuan untuk mewujudkan kualitas lanjut usia yang menjamin dirinya mampu untuk menjalani fungsi dan peranan sosialnya di masyarakat tempat dia tinggal. Penting bagi lanjut usia untuk tetap berinteraksi dan bersilaturahmi dengan lingkungan sekitarnya baik dengan sesama lanjut usia maupun dengan anggota masyarakat lainnya yang bukan termasuk lanjut usia. Interaksi dan silaturahmi pada lanjut usia ini memiliki manfaat agar menjaga hubungan dengan orang lain dan tidak mengurung diri di rumah karena dianggap sudah tidak produktif lagi. Adapun bentuk interaksi yang dapat diikuti oleh lanjut usia yaitu masih turut berpartisipasi pada pertemuan baik di tingkat RT, RW, pedukuhan, dan pedesaan. Lanjut usia yang masih aktif mengikuti kegiatan tersebut dapat bermanfaat bagi lanjut usia yaitu terpenuhinya kebutuhan sosial bagi lanjut usia yang juga dapat 
diterima oleh keluarga/ masyarakat, masih mampu bersosialisasi/ interaksi dengan lingkungan sosialnya, dan adanya pandangan yang baik mengenai keberadaan lanjut usia.

b) Pendampingan lanjut usia pada aspek kesehatan

Pendampingan pada aspek kesehatan memiliki tujuan untuk memelihara kesehatan fisik para lanjut usia. Bentuk pendampingan bagi lanjut usia yaitu adanya pemeriksaan kesehatan dari posyandu lansia secara berkala, pemberian makanan tambahan, adanya senam lanjut usia, diadakan rekreasi, dan adanya program Home Care Service dari Dinas Sosial.

c) Pendampingan lanjut usia pada aspek ekonomi

Pendampingan pada aspek ekonomi ini berfungsi untuk membantu lanjut usia meningkatkan keadaan ekonominya dengan memanfaatkan sumber daya yang ada. Bentuk pendampingan bagi lanjut usianya yaitu membuat tas dari kain perca dan kerajinan tas dari serat daun gebang. Pada proses pembuatan tas dari kain perca para lanjut usia hanya mengelem kain perca pada sebelum dijahit menjadi tas. Sedangkan pada proses pembuatan tas dari serat daun gebang para lanjut usia mengupas dan menyambung agel. Adanya kegiatan tersebut para lanjut usia dapat mengisi waktu luang dalam kehidupan sehari-harinya dengan tidak mengalami kebosanan di masa tuanya.

d) Pendampingan lanjut usia pada aspek spiritual
Pendampingan pada aspek spiritual memiliki tujuan untuk meningkatkan iman dan taqwa para lanjut usia untuk lebih rajin beribadah. Bentuk pendampingan bagi lanjut usia yaitu adanya pengajian rutin pada setiap malam Jumat Kliwon, adanya pengajian rabbana setiap bulannya, dan adanya kegiatan simak'an Qur'an. Kegiatankegiatan yang bersifat spiritual keagamaan tersebut menjadi sarana untuk beribadah dan sarana untuk menjalin silaturahmi antar sesama lanjut usia maupun lanjut usia dengan masyarakat sekitar di tempat tinggalnya.

2. Nilai-nilai kearifan lokal yang terdapat dalam pendampingan sosial lanjut usia di Desa Sidoluhur

Nilai-nilai kearifan lokal masyarakat yang terdapat dalam pendapingan sosial lanjut usia di Desa Sidoluhur yaitu nilai-nilai, norma-norma, adat istiadat, dan potensi lokal adanya lanjut usia. Adapun nilai-nilai dan norma-norma yang masih ada dan dianut oleh masyarakat Desa Sidoluhur yaitu masih memiliki sikap saling menghormati dan menghargai antar warga masyarakat demi tercipta suasana kerukunan dan kenyamanan dalam bermasyarakat; adanya budaya gotong royong yang masih kuat dalam masyarakat yang diwujudkan dengan saling tolong menolong dan saling membantu antar anggota warga masyarakat Desa Sidoluhur. Budaya gotong royong ini juga mencerminkan sikap kebersamaan antar warga masyarakat. Wujud gotong royong yang ada dalam pendampingan sosial ini yaitu adanya kebersamaan dan kerjasama antara pendamping 
dan lanjut usia serta antar sesama lanjut usia. Kebersamaan dan kerjasama ini terjadi ketika mengikuti kegiatan-kegiatan yang diadakan. Kegiatan seperti pendamping yang mendengarkan berbagai masalah dan keluhan yang dihadapi oleh lanjut usia. Kemudian secara bersama-sama bermusyawarah untuk mencari solusi untuk memecahkannya.

Masyarakat Desa Sidoluhur juga memiliki budaya sopan santun yang diwujudkan dengan penggunaan bahasa lokal (Bahasa Jawa) seharihari yang halus ketika berbicara dengan orang lain, baik dengan orang yang belum dikenal maupun dengan orang yang sudah dikenal. Sopan santun yang dalam Bahasa Jawa sering disebut dengan tata krama ini menjadi nilai kearifan lokal masyarakat Desa Sidoluhur.

Lanjut usia yang sudah memiliki banyak pengalaman dalam hidupnya dapat menjadi teladan bagi generasi penerusnya. Hal ini dapat terwujud melalui interaksi antara lanjut usia dengan orang yang melakukan pendampingan yang biasanya lebih muda dari lanjut usia. Interaksi antara lanjut usia dengan pendamping diwujudkan melalui mengucap salam ketika bertemu yang kemudia disusul dengan berjabat tangan dan saling menanyakan kabar. Interaksi yang terjadi dalam program ini menggunakan bahasa Jawa karena lanjut usia masyarakat Desa Sidoluhur biasa menggunakan bahasa Jawa dalam interaksi sehariharinya.

Penggunaan bahasa Jawa dalam pandangan masyarakat Jawa merupakan simbol dan perwujudan dari sikap sopan santun, menghormati yang lebih tua (lanjut usia), dan menghargai yang lebih muda (pendamping). Hal ini menunjukkan sikap saling peduli, bersahabat, dan ramah terhadap orang lain karena dalam penggunaan bahasa Jawa seseorang harus memperhatikan lawan bicaranya.

3. Manfaat pendampingan sosial bagi lanjut usia di Desa Sidoluhur

Pendampingan sosial yang dilakukan memiliki tujuan untuk lanjut usia agar hidupnya sejahtera dengan terpenuhinya segala jenis kebutuhan hidupnya. Selain itu, juga dapat menjadi mandiri yang tidak menggantungkan dirinya dengan orang lain. Manfaat yang diperoleh lanjut usia ketika mengikuti pendampingan sosial yaitu memiliki motivasi. Motivasi yang ada pada diri lanjut usia sangat berguna bagi dirinya agar dirinya mampu untuk mandiri dan tidak bergantung kepada orang lain.

Lanjut usia pada umumnya mengalami penuaan. Hal ini menyebabkan terjadinya kemunduran dari kesehatan fisik dan psikisnya. Keadaan fisik dan psikis yang dialami lanjut usia mempengaruhi tingkah laku dan kemandiriannya. Adanya pendampingan sosial untuk mengatasi masalah kesehatan fisik dan psikis lanjut usia seperti pemeriksaan kesehatan, kegiatan senam, dan rekreasi mampu memberikan manfaat bagi lanjut usia. Upaya yang dilakukan dapat menjaga dan meningkatkan kesehatan fisik dan psikis lanjut usia. Lanjut usia yang sudah mengikuti kegiatan tersebut keadaan fisiknya menjadi lebih bugar. Kondisi fisiknya yang baik ini dapat mendukung segala aktivitas dari lanjut usia 
sehingga dapat dikerjakan sendiri dan mandiri. Kondisi psikisnya pun akan baik yang diwujudkan dengan lanjut usia merasa bahagia dan senang ketika rekreasi.

Lanjut usia yang mengikuti kegiatan pelatihan keterampilan mendapatkan pengetahuan baru dan keterampilan yang sebelumnya belum dimiliki. Hasil karya lanjut usia dari pelatihan keterampilan memiliki nilai ekonomis yang dapat menunjang lanjut usia agar tetap memiliki penghasilan sendiri. Kemandirian dalam mencari penghasilan sendiri ini menjadi keuntungan bagi lanjut usia sendiri dan tidak memiliki ketergantungan dengan anggota keluarganya.

Bagi lanjut usia, kegiatan spiritual ini dapat memberikan arah dan tujuan yang jelas akan hidup lanjut usia. Selain itu, lanjut usia juga mendapat ketenangan batin. Lanjut usia dapat meningkatkan kegiatan ibadahnya dengan mempertebal iman dan lebih dekat dekat Tuhan sebagai bekal untuk kehidupan setelahnya. Aktivitas ini juga sebagai wadah bagi lanjut usia untuk menjaga silaturahmi baik antar sesama lanjut usia maupun dengan warga masyarakat yang lainnya.

\section{SIMPULAN}

Berdasarkan uraian hasil dan diskusi dapat disimpulkan bahwa program pendampingan sosial lanjut usia di Desa Sidoluhur yaitu pendampingan lanjut usia pada aspek sosial, kesehatan, ekonomi, dan spiritual. Nilai-nilai kearifan lokal masyarakat yang terdapat dalam proses pendampingan sosial lanjut usia yaitu penggunaan bahasa Jawa sebagai wujud saling menghormati dan menghargai; saling menjaga kerukunan; dan menjaga budaya gotong royong.

Pendampingan sosial bagi lanjut usia Desa Sidoluhur diharapkan mampu memberikan manfaat bagi lanjut usia yaitu dapat terpenuhinya kebutuhan para lanjut usia secara sosial, kesehatan, ekonomi, dan spiritualnya. Terpenuhinya kebutuhan dari berbagai aspek tersebut akan mampu memberikan kebermanfaatan untuk lanjut usia, kehidupan lanjut usia masih dapat sejahtera, dan masih dapat untuk produktif meski usianya sudah lanjut.

\section{DAFTAR PUSTAKA}

Biro Tata Pemerintahan Setda DIY. (2016). Statistik Penduduk Daerah Istimewa Yogyakarta. Yogyakarta: Setda DIY.

Dahliani. (2015). Local Wisdom In Built Environtment In Globalization Era. Journal of Educational and Research, Vol. 3, No. 6.Hurlock, Elizabeth B. (1980). Psikologi Perkembangan: Suatu Pendekatan Sepanjang Rentang Kehidupan. Jakarta : Erlangga.

Depsos RI. (2009). Pendampingan Pelayanan Sosial Lanjut Usia Berbasis Masyarakat. Jakarta : Depsos RI.

Gubernur DIY. (2011). Peraturan Daerah Nomor 5 Tahun 2011 tentang Pengelolaan dan Penyelenggaraan Pendidikan Berbasis Budaya. Retrieved from http://www.jdih.setjen.kemendagri. go.id/files/P DIY 5 2011.pdf

Neuman, W.L. (2014). Social Research Methods: Qualitative and Quantitative Approaches. United States of America : British Library.Rachmadhani, Arnis. (2011). Perkawinan Islam Wetu Telu Masyarakat Bayan Lombok Utara. Jurnal Analisa, Vol 18, No. 01. 
Diklus: Jurnal Pendidikan Luar Sekolah, 2 (3), September 2019 - 102

Rudi Hermawan

Sa-ngiamwibool, Amporm. (2012). Undang-Undang Republik Indonesia No.

Raising Learner Awareness Of Local $\quad 13 \quad$ Tahun 1998 tentang Wisdom In Tour-Related Project Kesejahteraan Sosial Lanjut Usia.

Teaching. Indonesian Journal of

Applied Linguistics, Vol 1, No2. 